\title{
NIETZSCHE COMO CRÍTICO DA MORAL
}

\author{
Clademir Luís Araldi \\ Universidade Federal de Pelotas
}

\begin{abstract}
This article tries to show the importance and the development of the critique of the moral in Nietzsche's work, since its first formulation to its most elaborated form, in the late works. After the analysis of the limits of the historical-genealogical investigation of the moral, the range and congruence of this alleged radical critique of the moral will be questioned.
\end{abstract}

Keywords: Critique; moral; ethics; will, genealogy.

Resumo: Este artigo procura mostrar a importância e o desenvolvimento da crítica da moral na obra de Nietzsche, desde sua primeira formulação até sua forma mais elaborada, na obra tardia. Após a análise dos limites da investigação histórico-genealógica da moral, serão questionados o alcance e a congruência dessa pretensa crítica radical da moral.

Palavras-chave: Crítica; moral; ética; vontade; genealogia.

$\mathrm{Na}$ Tentativa de autocrítica ao Nascimento da tragédia, de 1886, Nietzsche afirma que com sua metafísica de artista ele teria já expressado seu pendor crítico à interpretação moral da existência:

Aqui se anuncia, quiçá pela primeira vez, um pessimismo "além do bem e do mal", aqui recebe palavra e fórmula aquela "perversidade do modo de pensar" contra a qual Schopenhauer não se cansa de arremessar de antemão as suas mais furiosas maldições e relâmpagos - uma filosofia que ousa co-

\footnotetext{
*Versão modificada do texto da conferência apresentada no dia 24 de abril de 2008, no Colóquio "Temas de Ética e Filosofia Política", promovido pelo Programa de Pós-Graduação em Filosofia da Universidade Federal de Pelotas.
} 
locar, rebaixar a própria moral ao mundo da aparência e não apenas entre as "aparências" ou fenômenos (...), mas entre os "enganos", como aparência, ilusão, erro, interpretação, acomodamento, arte. ( $O$ nascimento da tragédia (NT). Tentativa de autocrítica, 5)

A justificação estética da existência seria oposta à justificativa moral cristã, segundo a qual a arte seria rebaixada ao nível da mentira. Entretanto, é na obra tardia que a crítica da moral é sistemática e programaticamente desenvolvida, a partir dos estudos da 'história natural da moral'. No prefácio de A genealogia da moral (1887), ele afirma ter sido o primeiro a tratar, com a radicalidade devida, a moral como problema, a olhar com suspeita profunda o "vasto país da moral", da moral que efetivamente existiu. A problematização de todas as concepções valorativas em sua base moral impulsionaria Nietzsche a repensar todos os tipos e métodos filosóficos, em sua vontade incondicional de verdade (cf. A genealogia da moral (GM), Prólogo, 5 e 6).

Enquanto crítico-genealogista da moral, Nietzsche coloca sob suspeita a crença em toda a moral. Essa suspeita se expressa em uma nova exigência:

Necessitamos de uma crítica dos valores morais, o próprio valor desses valores deverá ser colocado em questão: para isso é necessário um conhecimento das condições e circunstâncias nas quais nasceram, sob as quais se desenvolveram e se modificaram (moral como conseqüência, como sintoma, máscara, tartufice, doença, mal-entendido; mas também moral como causa, medicamento, estimulante, inibição, veneno), um conhecimento tal como até hoje nunca existiu nem foi desejado (GM, prólogo, 6).

Embora tivesse formulado, de modo provisório, no livro de aforismos Humano, demasiado humano (HH I, 1878), as primeiras hipóteses sobre a origem dos sentimentos e valores morais, é em Além do bem e do mal e em A genealogia da moral que os estudos históricos da moral assumem importância decisiva no procedimento genealógico, tanto em sua vertente crítica, quanto em sua forma construtiva, através da criação de novos valores.

Investigaremos neste artigo a congruência do projeto nietzschiano de realizar a 'história efetiva da moral', para além das limitações da genealogia dos sentimentos morais, de Paul Rée, da fundamentação racional da moral 
kantiana e da ética da compaixão, de Schopenhauer. O filósofo genealogista alemão elabora exaustivamente uma história efetiva (natural) da moral? Caso isso não ocorra, seus propósitos críticos estariam comprometidos? Essas questões merecem um exame atento.

\section{A base histórica da crítica da moral no pensamento de Nietzsche}

A abordagem histórica da moral é formulada pela primeira vez em Humano, demasiado humano I, no capítulo "Contribuição à história dos sentimentos morais". Nietzsche não fornece propriamente um novo método de análise da moral, pois partilha de muitos conceitos e argumentos da obra, na época recém-publicada, de Paul Rée, $A$ origem dos sentimentos morais (1877). Nessa obra, Paul Rée discute os conceitos de prazer e desprazer, de vício e virtude, de utilidade geral, em Hume, em Schopenhauer e no utilitarismo moral inglês. À semelhança de Hume, Schopenhauer, e da interpretação recente de Rée, também Nietzsche deriva os sentimentos morais dos sentimentos de prazer e desprazer. Na época tardia, contudo, ele se distancia dessa abordagem, ao desenvolver a doutrina da vontade de poder, como novo critério descritivo e valorativo.

Apesar de propor uma análise histórica dos sentimentos morais, o autor de Humano, demasiado humano (HH I) expõe as inovações da 'observação psicológica'. A psicologia seria, então, a ciência que investiga o surgimento e o desenvolvimento dos sentimentos morais ${ }^{1}$. Os 'moralistas franceses' La Rochefoucauld, Montaigne, Vauvenargues, Chamfort, Stendhal e Pascal foram, nessa ótica, pioneiros na anatomia moral do humano. Mas é em Paul Rée que Nietzsche mais se apóia em seus estudos, compreendendo-se como um continuador de sua obra:

"O homem moral" - diz P. Rée - "não está mais próximo do
mundo inteligível (metafísico) que o homem físico". Esta
proposição, temperada e afiada sob os golpes de martelo do
conhecimento histórico, talvez possa um dia, em algum futu-
ro, servir como o machado que cortará pela raiz a "necessida-
de metafísica" do homem - se para a bênção ou para a maldi-
ção do bem-estar geral, quem saberia dizê-lo? - mas, em todo
o caso, como uma tese das mais graves conseqüências, simul-

${ }^{1}$ Cf. MARTON, 1990, p. 69. 
taneamente fecunda e horrenda, e olhando para o mundo com aquela dupla face que possuem todos os grandes conhecimentos (HH I, 37).

Questionamos a pretensa originalidade da análise psicológicohistórica nietzschiana da moral, com a admissão do que foi herdado dos mestres da sentença psicológica e dos anatomistas da moral. Entretanto, há pelo menos duas teses, que marcam o distanciamento de Nietzsche em relação a P. Rée: 1) A defesa do egoísmo como necessário para a geração dos fenômenos morais (cf. HH I, 107) e 2) A ênfase nos costumes e na tradição, como fonte para a distinção entre bom e mau (como obediência ou ofensa à tradição), entre moral e imoral (cf. HH I, 96).

O espírito livre (der Freigeist), nessa abordagem, pode ser considerado o tipo superior de homem, autônomo e soberano, em sua tentativa de levar às últimas conseqüências o desenvolvimento autocrítico da vontade moral de verdade: "Filosofia do espírito livre (Freigeistereı), enquanto última conseqüência da moralidade até aqui” (X, 1(42) - julho-agosto de $1882^{2}$ ). Não haveria, desse modo, uma mera negação ou abandono da moralidade da tradição, devido às suas bases teóricas falsas. A ênfase está na superação (Überwindung) da moral: "A moral é impelida ao seu ponto máximo e ultrapassada através da 'filosofia do espírito livre" "3. Quando Nietzsche se assume como "herdeiro de milênios do espírito europeu" ( $A$ Gaia Ciência (GC), 377), ele dispõe-se a levar a cabo tal movimento moral e ultrapassá-lo. O conhecimento de que a vida é imoral, de que repousa sobre erros e falsificações guia, primeiramente, ao desejo de destruição, de negação da vida. No entanto, a última conseqüência da moral seria sua própria negação: "A moral deve negar a si mesma” (X, 2(6) - verão-outono de 1882).

A investigação crítica do surgimento e desenvolvimento da moral, que ocorre a partir dos escritos de 1876, está intimamente ligada à crítica da metafísica. Os estudos acerca da origem dos sentimentos morais do segundo capítulo de Humano, como vimos, são um primeiro esforço de distanciamento e de libertação da moral, dos seus preconceitos e erros. A história dos

2 Citaremos os fragmentos póstumos de Nietzsche, segundo o critério adotado para as obras de Nietzsche na Kritische Studienausgabe (KSA), organizada por G. Colli e M. Montinari. O algarismo romano indica o volume e os arábicos, que a ele se seguem, o respectivo fragmento póstumo. As obras de Nietzsche serão citadas de modo abreviado, conforme indicado na primeira ocorrência de cada uma delas.

${ }^{3} \mathrm{KSA}$ X, 4(16). Confira também os fragmentos póstumos X, 6(1) e X, 6(4) - inverno de 1882-1883. 
sentimentos morais poderia ser considerada, desse modo, como a história do surgimento e da fixação de erros, tais como o da responsabilidade e o da "liberdade inteligível" (cf. HH I, 39). O filósofo pondera, contudo, que é possível constatar três fases constituintes da moralidade até então, nas quais a utilidade, o princípio da honra e a autonomia do indivíduo seriam os respectivos marcos de cada fase. Com o 'indivíduo coletivo' (das CollectivIndividuum) seria atingido um grau maior de conhecimento e de autodeterminação, pois ele, enquanto membro da coletividade, torna-se legislador (cf. HH I, 94). Assim como os pressupostos metafísicos, também os preconceitos morais, malgrado as formas distintas de manifestação, perpassariam a religião (vista como moral, mandamento de deus, ou dever para com a divindade) e a arte (moral do gosto).

Ao contrário dos que continuam aprisionados à moral e aos costumes, o espírito livre é considerado um indivíduo singular (der Einzelne) (cf. HH II, $O$ andarilho e sua sombra, 350). Para atingir a liberdade madura do espírito, a autodeterminação e o autodomínio, esse novo tipo (além-da-moral) necessita não só perder a si mesmo, mas também afastar-se de todo o seu passado, seja de seu passado animal, dos hábitos, das crenças.

O aforismo "A dupla pré-histórica do bem e do mal”, em que a abordagem histórica é propriamente tematizada, traz poucos argumentos e exemplos históricos, para provar a tese de que o conceito de bem e mal surgiu primeiro "nas tribos e castas dominantes" e, depois, nos oprimidos e impotentes (HH I, 45). Em Assim falou Zaratustra (ZA), essa perspectiva histórica é retomada, de modo breve mas enfático, à luz da vontade de poder (der Wille zur Macht). As tábuas valorativas de bem e mal atestam como alguns povos triunfaram e fixaram novos tipos hegemônicos. Na seção "De mil e um fitos”, é feita alusão simbólica a vários povos, como os gregos, persas e judeus (cf. ZA I, De mil e um fitos). Do mesmo modo, em "Da superação de si mesmo" (ZA III), Nietzsche não prova a tese de que há uma "lei fundamental da vida”, a saber, a lei da auto-superação da vida. Trata-se de algo que a "própria vida" revelou a Zaratustra; a partir do qual ele equipara a vida à vontade de poder. A vontade de ser senhor atuaria também nas formas mais baixas da hierarquia, na vontade do servo.

Entendemos que Nietzsche procura corrigir o déficit de argumentação de sua distinção entre os tipos fortes e fracos de moral (da moral dos senhores e dos escravos) na obra Além do bem e do mal (BM), com a formulação hipotética da doutrina da vontade de poder (cf. BM, 36) e com o desenvol- 
vimento do projeto genealógico da moral, da 'história natural da moral'. Apesar da importância desse projeto, o autor dedica apenas o capítulo V para a investigação histórica. O capítulo IX, “O que é nobre?”, desenvolve ainda alguns aspectos dessa pesquisa, mas de modo um tanto evasivo, pois no desfecho é re-introduzida a proposta de uma filosofia trágica, de uma nova configuração do dionisíaco, no plano filosófico, não mais no plano estético.

Como ele próprio reconhece, Além do bem e do mal é uma crítica abarcante da modernidade 4 . Seguindo a mesma estrutura formal de Humano, demasiado humano, o filósofo solitário vincula a crítica da metafísica à crítica da moral, que adquire uma maior amplitude, ao propor o 'único' questionamento radical da moral até então. A crítica da moral é a instância central para o 'ataque' a todas as esferas normativas da modernidade, no direito, na sociedade, na religião e na cultura como um todo. Para levar a cabo o que seria a única crítica radical da moralidade, Nietzsche necessita primeiro oferecer argumentos consistentes acerca do enraizamento histórico da tipologia da moral, da distinção entre nobre e escravo, e do critério normativo que a ela conduz.

Questionamos o alcance dessa crítica da modernidade, pois o critério que possibilitaria elucidar a base naturalista da moral, a "lei fundamental da vida" - a vontade de poder enquanto auto-superação, vontade de ser senhor, de si e do que é estranho - é formulada de modo hipotético, ocultando uma série de pressuposições e lacunas, que a tornam problemática na função que exerce como instância crítica e normativa. Por outro lado, a 'tipologia da moral' é apresentada somente no capítulo IX, e de um modo muito sucinto:

Numa perambulação pelas muitas morais, as mais finas e as mais grosseiras, que até agora dominaram e continuam dominando na terra, encontrei certos traços que regularmente retornam juntos e ligados entre si: até que finalmente se revelaram dois tipos básicos, e uma diferença fundamental sobressaiu. Há uma moral dos senhores e uma moral dos escravos. (BM 260)

Nietzsche aponta aqui o resultado final do que seria o longo processo de investigação histórica da moral, do qual ele não fornece reconstruções e apontamentos suficientes. Em todas as morais que já existiram e ainda são

${ }^{4}$ Cf. Ecce homo (EH). Além do bem e do mal, 2. 
efetivas, haveria certos traços comuns, que são agrupados em dois tipos: 1) afirmativos, na moral dos senhores e 2) negativos, na moral dos escravos. Questionamos se há aqui uma descrição dos "fatos" básicos que fundam as morais. Não haveria uma simplificação tendenciosa, no modo como Nietzsche ressalta determinados exemplos históricos, para provar aquilo que ele intui, compreende como sendo "a lei fundamental da vida"?

Os questionamentos apresentados apontam para o caráter incipiente $\mathrm{e}$ lacunar do projeto de naturalização da moral em Além do bem e do mal. É necessário, primeiramente, contextualizar esse projeto. Além do bem e do mal foi concluído no início de abril de 1886 (a impressão ficou pronta em 21 de julho desse ano), na época em que Nietzsche reitera a intenção de desenvolver o projeto da obra $A$ vontade de poder, no plano teórico e prático. Articulado a esse projeto - que então figurava como o de maior envergadura - ele tencionava continuar a obra de 1886. Desses apontamentos resultaram a obra Para a genealogia da moral - um escrito polêmico, que deveria servir de adendo à obra recém publicada. No ano seguinte (em junho de 1887) aparece também o escrito "O niilismo europeu”, em que é exposta a lógica de autodissolução da valoração moral. As reflexões históricas e tipológicas sobre a moral foram desenvolvidas principalmente nos meses subseqüentes, na Genealogia da moral, na investigação das três formas históricas de desdobramento do niilismo moral: o ressentimento, a má consciência e o ideal ascético.

Que o livro $A$ genealogia da moral não é a conclusão dos estudos sobre a história da moral e suas conseqüências niilistas, fica bem claro no final da obra, em que Nietzsche explicita o projeto de tratar esses temas "com maior profundidade e severidade" na obra que estava preparando, $A$ vontade de poder. Ensaio de uma transvaloração de todos os valores (cf. GM III, 27). Tal obra não foi concluída; apenas projetos, apontamentos e alguns aspectos gerais foram redigidos 5 . A menção imediatamente posterior (cf. XII, 9(83)) de redação da segunda parte da Genealogia serve para que questionemos a completude do programa da Genealogia da Moral. O que essas lacunas e limitações do projeto genealógico acarretam para a pretensa crítica radical da moral?

Antes de analisar a nova proposta de uma condução não moral da vida, pretendemos questionar o alcance dos estudos históricos da moral em-

${ }^{5} \mathrm{Cf} . \mathrm{XII}, 5(75)$ e os grupos de fragmentos 7 e 8 desse volume. 
preendidos por Nietzsche nos escritos (i) do período intermediário e (ii) nos últimos anos de produção filosófica.

(i) Em Humano, demasiado humano, Nietzsche se concentra mais no método de observação psicológica, a partir dos resultados já alcançados pelos psicólogos e moralistas anteriormente mencionados. A contribuição decisiva que ele traria à "História dos sentimentos morais" é escassamente elaborada. O surgimento da moral nos povos primitivos deve-se à ligação incondicional dos seres humanos às leis, à tradição e aos costumes. Sem abandonar as teses de Hume e de P. Rée, de que as relações de prazer e desprazer estão na base dos sentimentos morais, ele afirma que há um prazer para o indivíduo em seguir costumes e hábitos, unido à utilidade geral: a conservação da comunidade. $\mathrm{O}$ argumento proposto por ele é de que o costume é condição necessária para o estabelecimento de formas humanas de vida, estruturadas socialmente. Desse modo, o Estado está na gênese da moralidade, pois graças à sua coerção, ele garante a estabilidade e a respeitabilidade dos costumes. Mesmo "os mais severos modos de vida" adquirem, com a repetição, o estatuto de hábitos, prazerosos aos indivíduos que os seguem (cf. HH I, 97, 98). Essa análise é aplicada ao surgimento de todas as comunidades e povos com longa duração. (A menção aos judeus e aos gregos da época de Sócrates serve como ilustração desse argumento) Mas não surge de uma história comparada do estabelecimento de valores de povos situados em épocas distintas. Mesmo no aforismo de Aurora (A), "Conceito de eticidade do costume", o reconhecimento do poder do costume ao longo de milênios da história humana não é acompanhado de uma análise histórica minuciosa. É a retomada da tese de Humano, de que a obediência à tradição constitui o ético. Ou seja, no mais longo período (pré-história) da vida humana, a 'eticidade do costume' (Sittlichkeit der Sitte), o costume era tudo:

\footnotetext{
- Originalmente fazia parte do domínio da moralidade toda a educação e os cuidados da saúde, o casamento, as artes da cura, a guerra, a agricultura, a fala e o silêncio, o relacionamento de uns com os outros e com os deuses: ela exigia que alguém observasse os preceitos sem pensar em si como indivíduo (A, 9).
}

Nos brâmanes e nos romanos antigos essa tradição ética propunha o sacrifício da individualidade, em detrimento da afirmação da comunidade e 
do poder dos costumes. Com Sócrates começa um novo caminho, da moral voltada ao indivíduo, na qual o bem do indivíduo é ambicionar sua própria felicidade (cf. A, 9).

Além de oferecer poucas análises de como surgiram o bom e o mau na moral, a partir dos sentimentos e ações na época mais antiga da humanidade, Nietzsche está muito próximo de Paul Rée, no modo como este interpreta, a partir de Darwin, o instinto social em ligação com a seleção natural ${ }^{6}$. $\mathrm{Na}$ discussão com o utilitarismo moral inglês, o primeiro concorda que, no período da eticidade do costume, o princípio moral utilitarista do bem-estar geral (da maior utilidade geral) garante a manutenção do indivíduo coletivo. $\mathrm{Na}$ moral moderna do indivíduo maduro, contudo, os interesses e vantagens próprios devem ser compatíveis com a maior utilidade para o conjunto (cf. HH I, 95). No homem bom, que pratica de bom grado o que é ético (costume), se fixaria uma espécie de segunda natureza.

(ii) No último período em que Nietzsche desenvolve a versão mais acabada do método genealógico, o esquema básico para a compreensão da história da moral é o mesmo da época intermediária, constituído por três fases. Essas três fases perfazem o longo processo de surgimento, desenvolvimento e auto-superação da moral:

1) A eticidade do costume. Trata-se da pré-história da espécie humana, em que ocorre a transição do estado de natureza para as primeiras formações culturais. Não há indivíduo autônomo, fora dos costumes, da obediência e da vida da espécie (cf. A, 9).

2) O período moral propriamente dito surge com a constituição de indivíduos reflexivos, com consciência moral, que presumem determinar pela razão os motivos das ações. Iniciando com Sócrates, esse período é caracterizado pela responsabilidade moral, e desenvolve-se no sentido do progresso moral e histórico, seja no cristianismo, na moral kantiana ou no utilitarismo moral. O indivíduo está submetido à coerção das instituições sociais e de leis (convencionais, arbitrárias) (cf. GM II, 2).

3) No período extra-moral atinge-se o indivíduo autônomo, soberano, legislador (cf. GM II, 2). Esse indivíduo além da moral é resultado da disciplina ascética da moral e da razão, das instituições sociais e práticas genéricas comuns (do rebanho). O passo para a fase pós-histórica é pouco esclarecido

${ }^{6}$ Cf. RÉE, 2004, p. 131. 
por Nietzsche, uma vez que não são analisadas as condições necessárias para a libertação de todas as normas e coerções, do indivíduo que quer se assumir como sujeito ético (egoísta), de suas próprias leis e condutas. Para engendrar o tipo nobre futuro é preciso, de qualquer modo, uma nova disciplina e educação.

Como ponto de partida dessa análise genealógica da moral, é necessário admitir a "imoralidade da natureza e da história" (que o próprio Kant já teria reconhecido). Herdeiro de uma longa crise dos fundamentos e dos valores da moral, Nietzsche começa por suspeitar da moral, apontando para o caráter perspectivista de todas as produções e avaliações humanas. Após abandonar as pretensões de fundamentação da moral, o genealogista da moral assume outra tarefa: formular e classificar conceitualmente as distintas experiências morais de valor ocorridas ao longo do tempo, acessíveis na "escrita hieroglífica quase indecifrável do passado moral humano" (GM, Prólogo, 6). A história da moral busca explicitar as diferenças de valores e de avaliação (p. ex., do bom e do mal de cada povo, ou cultura), sem se deter em nenhum preconceito moral (como p. ex., a compaixão), nem às idéias modernas, como a democracia e o bem-estar da maioria. Em todos os modos de vida da pré-história e da história moral humana manifesta-se o desejo de dominar, de conquistar, subjugar, explorar, em suma a vontade de poder, traço fundamental da vida e do mundo. Quando a vontade de poder declina, a moral se torna antinatural, como é o caso da moral cristã, que triunfou sobre os valores aristocráticos e seu naturalismo na moral, voltando-se contra os instintos da vida. (Crepúsculo dos ídolos (CI), Moral como antinatureza, 4).

Tratar a moral como um problema implica em questionar o valor da verdade e os impulsos a ela subjacentes ${ }^{7}$. A análise nietzschiana da moral possui já no seu início uma conotação crítica, na medida em que desmascara a pretensão de verdade da religião, da metafísica e da ciência, apontando para as fontes ascético-morais das mesmas. Ela possui também uma acepção posi-

\footnotetext{
7 O questionamento da verdade a partir das motivações morais nela ocultas ocorre já nos escritos anteriores. Num escrito póstumo do final de 1876 e do início de 1877, Nietzsche enfatiza que a moral diz respeito somente à opinião, ao âmbito do intelecto, do caráter abreviador e falsificador do intelecto. 0 sentido moral, do mesmo modo que o sentido para as artes (der Sinn für die Künste) está fundado em juízos e conclusões falsos. Assim sendo, "o sentido da verdade é mesmo o florescimento supremo e mais poderoso desse sentido moral." (KSA VIII, 23(152))
} 
tiva, na medida em que se apresenta como projeto de criação de novos valores e como defesa do 'egoísmo' (Selbstsucht). Nesse sentido, a alteração do termo Freigeist - para der freie Geist, em Além do bem e do mal, aponta para uma profunda modificação de seu significado. Enquanto na primeira acepção Nietzsche tinha em vista o engendramento do(s) espírito(s) livre(s) em geral (como cético, que assume a postura passiva de pairar sobre costumes, valores, sem se deter a nada), na segunda acepção há a progressiva identificação do filósofo com o tipo espírito livre, que passa a ser porta-voz de seus novos pensamentos, e assume uma conotação mais positiva: a de legislador, de filósofo do futuro.

\section{Os limites da crítica da moral}

Em relação à tradição da filosofia moral, os alvos principais da crítica nietzschiana são a moral kantiana e a moral da compaixão, na formulação de Schopenhauer. Ele não realizou estudos sistemáticos sobre a filosofia moral de Kant (da Fundamentação da metafísica dos costumes e da Crítica da razão prática). A principal crítica generalizante é que o êxito de Kant, enquanto filósofo da moral, é um êxito de teólogo: "Entre os alemães compreende-se de imediato, quando digo que a filosofia está corrompida pelo sangue dos teólogos. O pastor protestante é o avô da filosofia alemã, o protestantismo mesmo é o seu peccatum originale" (O Anticristo (AC), 10). Nisso se evidencia a influência da crítica de Schopenhauer à fundamentação da moral dada por Kant, contida nas obras Sobre a liberdade da vontade e Sobre o fundamento da moral. Segundo Schopenhauer, a forma imperativa e o conceito de dever da ética kantiana provêm da moral teológica (linguagem do Decálogo). Essa disposição de obedecer à lei moral é designada de "moral dos escravos". A razão não é o fundamento de determinação da vontade dos seres humanos. Não é possível pensar a razão como constitutiva de "seres racionais em abstrato” fora do homem. Para o filósofo pessimista, a motivação moral é real, fáctica, empírica, e não proveniente de uma lei (da razão pura prática, resultado de um processo de pensamento abstrato, de uma faculdade especial). $\mathrm{O}$ ser íntimo e eterno do homem não consiste na razão, como queria Kant, mas na vontade . $^{\circ}$

${ }^{8}$ Cf. SCHOPENHAUER, 2001, p. 37 e 38. 
Schopenhauer, no entanto, busca ainda o fundamento metafísico da moral. A experiência da compaixão proviria do ser em si das coisas. Esses fatos, comprovados na sabedoria dos povos antigos e nas religiões pessimistas, assegurariam a tendência ético-metafísica da vida. Assim sendo, a compaixão inata em todo homem é o único fundamento para as ações não egoístas, as únicas ações com valor moral. A essência una e única, comum a todos os seres, está além de toda multiplicidade fenomênica: esse é o ponto de partida da metafísica da ética.

Também Nietzsche critica a fundamentação da moral dada por Kant (e também os demais projetos morais), a partir da vontade. Entretanto, não se trata mais da Vontade como essência Una, mas da vontade de poder, em sua multiplicidade. Essa é a instância crítica nietzschiana. Schopenhauer teria permanecido no meio do caminho, por deter-se em preconceitos morais, da ética da compaixão, e por afirmar o valor moral das ações não egoístas.

Nessa perspectiva, a tarefa kantiana de criticar a razão mediante a própria razão é paradoxal. Esse procedimento, em que a razão é, ao mesmo tempo, juiz e réu, é ilegítimo e absurdo, e ocultaria interesses escusos, da destinação moral da razão: "A resposta correta seria, isto sim, que todos os filósofos construíram sob a sedução da moral, inclusive Kant”, cuja tarefa no fundo seria a de "aplainar e preparar o solo para majestáticos edifícios morais” ( $A$, Prólogo, 3). Visto que o conceito de moral (a razão pura prática) não está na essência do mundo, a razão não teria poderes para legislar. Essa é a tarefa dos filósofos do futuro.

Nietzsche critica, desse modo, a legitimidade e o alcance da filosofia crítica de Kant, ao suspeitar que na pressuposição do caráter incondicionado da lei moral, cessa a investigação crítica e começa a teologia moral. O filósofo de Königsberg procurou tornar científica, através do conceito (faculdade) de razão prática, essa falta de consciência intelectual, de valores morais herdados, as exigências do "tu deves" (cf. AC, 12). No fundo, como comenta Deleuze, os ideais supremos da razão teriam um caráter incriticável ${ }^{9}$. A crítica de Kant acreditaria ainda no que ela critica. Assim, o genealogista da moral começa a investigar a velha confiança na moral, com a qual os filósofos, há alguns milênios construíram, como se fosse o fundamento mais seguro $(A$, Prólogo, 2). A própria confiança na razão e nos juízos de valor lógicos é um evento moral. O filósofo que quer radicalizar a crítica suspeita, investiga e,

${ }^{9}$ Cf. DELEUZE, 1976, p. 73-77. 
por fim, chega a afirmar: "a maior parte do pensamento consciente deve ser incluída entre as atividades instintivas, até mesmo o pensamento filosófico" (BM, 3).

Ao questionar o valor da moral em geral, Nietzsche se confronta com seu antigo mestre Schopenhauer. O maior perigo e tentação para a humanidade estaria justamente em entronizar a compaixão, o não egoísmo e a abnegação como valores superiores, válidos em si, como fez o filósofo pessimista. A superestimação da compaixão por parte dos filósofos ${ }^{10}$ expressaria uma vontade que se volta contra a vida, como um sintoma "dessa nossa inquietante cultura européia; como o seu caminho sinuoso em direção a um novo budismo?” (GM, Prólogo, 5).

A partir de Humano, demasiado humano são investigadas as manifestações do impulso altruísta (benevolência, compaixão), a partir das relações de poder, do desejo de dominar. A compaixão é o poder dos fracos e sofredores, que descobrem a vantagem própria em suscitar nos outros piedade: "a sede de compaixão é uma sede de gozo de si mesmo, e isso à custa do próximo" (HH I, 50). Do mesmo modo, quem pratica a compaixão para com o que sofre, está exercitando sua força e seu sentimento de superioridade em relação ao mais fraco e digno de pena. A questão não é mais investigar o valor moral das ações não egoístas, mas mostrar que a ética da compaixão é uma interpretação falsa de certos fenômenos. Todas as ações humanas seriam egoístas, visam ao domínio, à intensificação do sentimento de prazer pessoal; mesmo na aparente humildade e no altruísmo, elas visam à fruição de si mesmo, de dois modos: 1) como prazer da emoção (compaixão trágica) e 2) quando impele à ação, como prazer da satisfação no exercício do poder $(\mathrm{HH}$ I, 103). Entre boas e más ações há apenas diferenças de grau, pois expressam o desejo único de autofruição do indivíduo.

Nietzsche critica a idéia cristã de 'próximo' e a essência una de tudo o que vive e sofre, de Schopenhauer, ao defender uma hierarquia dos seres humanos, entre fortes e fracos, entre os que devem legislar, comandar, ter independência, e os que devem obedecer, os fracos e dependentes: "se as dores

\footnotetext{
${ }^{10}$ Nesse ceticismo cada vez mais radical há também uma autocrítica ao pensamento de juventude, na época em que Nietzsche via em Schopenhauer seu "pai espiritual", quando ele afirmava a compaixão trágico-dionisíaca (Dioniso, fundo primordial do mundo, como o eterno padecente e cheio de contradição, causa de todos os sofrimentos dos seres individuais). A tragédia mostraria a compaixão (sofrer com), a unificação do espectador com os sofrimentos do herói (do deus-artista Dioniso), da qual nasceria um prazer superior.
} 
do mundo fossem juntadas numa só, quem poderia ousar dizer que a visão dela nos iria necessariamente seduzir e obrigar à compaixão, e desse modo, à duplicação da dor?...” (BM, 30) A crença na moral da compaixão seria típica de uma época democrática, e Schopenhauer seu principal apologeta, que procurava ainda o verdadeiro fundamento da moral na velha prescrição "não fere a ninguém, antes ajuda a todos no que podes" (BM, 187). O homem moderno possui um ódio mortal ao sofrimento, por isso busca sua redenção nos valores gregários, da moral do rebanho. A isso ele contrapõe a "disciplina do grande sofrimento", em que o homem deve ser ao mesmo tempo criador e criatura, legislador e súdito.

Se o maior perigo nos tempos modernos reside na compaixão pelo homem que sofre, a solução está em criar um tipo de homem afirmativo, digno de ser admirado e temido. Essa é a tarefa dos imoralistas, espíritos livres e legisladores do futuro.

O benevolente e o compassivo foram avaliados "bons" porque eram úteis para a manutenção e fortalecimento da comunidade ou povo. $\mathrm{Na}$ mudança de hábitos e costumes, a compaixão pode ser algo "mau", nocivo, prejudicial (p. ex., entre os gregos) (cf. HH I, 96). Assim sendo, ela não é um sentimento moral inato: "saber que o outro sofre é algo que se aprende" (HHI, 101). Para poder sentir compaixão é preciso um bom desenvolvimento da força da imaginação.

Nietzsche procurava ligar o ato de negar, de criticar, com a afirmação e com a criação. Entretanto, nos últimos anos de produção filosófica, preponderou a parte crítica de sua tarefa, a parte que diz Não à moral da mediocridade e da compaixão do homem moderno. A tarefa de legislar, de criar novos valores (transvaloração de todos os valores) ficaria reservada aos filósofos do futuro, "os verdadeiros filósofos, que comandam e legislam" (BM, 211). Kant, com sua tentativa de submeter a vida humana à legislação da razão (moral) é ainda um "trabalhador filosófico), uma mera propedêutica para a tarefa dos filósofos autênticos. Nietzsche, como crítico da moral, projeta a si mesmo ao fim do longo processo da moral, quando intenta efetivar em si a auto-supressão da moral (die Selbst-Aufhebung der Moral), ao termo do qual surgiria o indivíduo soberano, autônomo e além-da-moral. Se a vontade de poder da vida afirmativa, do tipo de homem nobre é o critério para o estabelecimento de novos valores, não fica claro em quem e quando essa tarefa poderia ser executada: 
Algum dia, porém, num tempo mais forte do que esse presente murcho, inseguro de si mesmo, ele virá, o homem redentor, o homem do grande amor e do grande desprezo, o espírito criador cuja força impulso afastará sempre de toda transcendência (...). Esse homem do futuro, que nos salvará não só do ideal vigente, como daquilo que dele forçosamente nasceria, do grande nojo, da vontade de nada, do niilismo, esse toque de sino do meio-dia e da grande decisão, que torna novamente livre a vontade (...), esse vencedor de Deus e do nada - ele tem de vir um dia (GM II, 24).

A tarefa de consumar a criação de novos valores só poderia ser assumida por um ser de caráter nobre, que possuísse uma organização hierárquica distinta de seus impulsos. Na Genealogia da moral, em que a crítica da moral é metodologicamente desenvolvida, o projeto de criação de valores é referido ao homem do futuro (Cf. GM II, 24). Em Além do bem e do mal, são os filósofos (em oposição aos trabalhadores filosóficos) quem assumiriam a tarefa de legislar, de criar novos valores (BM, 211). Nessas obras, contudo, Nietzsche não consegue ir muito além da propedêutica crítica ao projeto de transvaloração de todos os valores.

Nos escritos sobre a moral do período tardio (principalmente de 1885 a 1888), o caráter artístico é inserido enfaticamente no processo de criação de valores. A moral somente poderia ser justificada como fenômeno estético, visto que os valores e juízos morais originaram-se de percepções estéticas (como modos de prazer e desprazer: agradável, belo, repulsivo, desprezível), sem as oposições metafísicas absolutas de valores (cf. IX, 11(78)). É necessário questionar a coerência do projeto nietzschiano, de reduzir a moral à estética, através da criação de estimativas de valor estéticas, válidas somente para indivíduos singulares, que se colocam para além do período moral da humanidade.

$\mathrm{Na}$ investigação genealógico-histórica da moral, que tornaria possível a re-naturalização do homem, Nietzsche assume como sua prerrogativa as condições preliminares para chegar ao período extramoral, no qual surgiria o indivíduo soberano, legislador, autônomo e livre para criar valores. Mas o próprio período moral, da história universal, esgotaria-se por si mesmo:

Mas coloquemo-nos no fim do imenso processo, ali onde a árvore finalmente sazona seus frutos, onde a sociedade e sua 
moralidade do costume finalmente trazem à luz aquilo para o qual eram apenas o meio: encontramos então, como o fruto mais maduro da sua árvore, o indivíduo soberano, igual apenas a si mesmo, novamente liberado da moralidade do costume, indivíduo autônomo supramoral (...), em suma, o homem da vontade própria, duradoura e independente, o que pode fazer promessas - . (GM II, 2)

Nessa interpretação, é a própria moralidade que se volta contra si mesma, contra seus pressupostos e princípios, para, por fim, desvelar a imoralidade reinante na natureza e na história ${ }^{11}$. Na conclusão da Genealogia da moral, à diferença da obra precedente, Nietzsche se coloca como um dos herdeiros "da mais longa e corajosa auto-superação da Europa"12 (e não como o último discípulo do deus-filósofo Dioniso), invocando, contudo, uma obscura lei da vida:

Todas as grandes coisas perecem por obra de si mesmas, por um ato de auto-supressão [durch einen Akt der Selbstaufhebung) ${ }^{13}$ : assim quer a lei da vida, a lei da necessária "autosuperação” que há na essência da vida - é sempre o legislador mesmo que por fim ouve o chamado: "patere legem, quam ipse tulisti” [sofre a lei que tu mesmo propuseste] (GM III, 27).

A questão acerca do sentido da existência e do sofrimento humano não teve uma solução sustentável na moral cristiano-ascética. É na ética da nobreza que o primeiro 'filósofo trágico' repensará as noções de sentido e valor, assim como os conceitos de autonomia, egoísmo, liberdade e responsabilidade.

Pode o indivíduo soberano (ou o tipo nobre) surgir do seu oposto, do tipo escravo/animal de rebanho? Ou ele seria engendrado a partir das poucas personificações históricas do tipo nobre (na Grécia e na Roma antigas)? Ou de uma síntese de ambos os tipos básicos, dos dois momentos determinantes,

\footnotetext{
${ }^{11}$ Cf. GM III, 27 e GC, 357. A mesma descrição do processo de autodestruição e auto-superação da moral ocorre no escrito de 1887: "O niilismo europeu" (o fragmento de Lenzer-Heide).

${ }^{12}$ Acerca da posição de Nietzsche na História do espírito, confira GIACÓIA, 1997, p. 103-106.

13 O termo 'auto-supressão' (Selbstaufhebung) é empregado poucas vezes na obra de Nietzsche, em relação à moral, à justiça e à sociedade (cf. VII, 7(174), A, Prefácio, 4, GM II, 10 e XII, 5(72)). Apesar do acento hegeliano, ele é usado no texto supracitado de modo enfático, para marcar o fim do processo de dissolução da moral, e para propiciar a transição para uma nova época.
} 
da pré-história e do período moral? Nietzsche não define com clareza as propriedades do tipo nobre futuro. Não fica evidente se a nobreza é algo apenas herdado, típico dos que possuem "instinto para a hierarquia" (nesse sentido, tratar-se-ia de um projeto voltado à fisiologia), ou se ele aponta para um tipo a ser cultivado e atingido pela cultura, independente da conformação biológica dos instintos.

Ao colocar o eu individual, o si-mesmo (Selbst) no centro de suas investigações, parece evidente, num primeiro momento, que a nova proposta ética está voltada ao indivíduo, numa espécie de filosofia prática, da arte de (bem) viver. Essa é a tese de W. Schmid, para quem Nietzsche, após confirmar a morte do sujeito substancial, identitário, estabeleceria um novo sujeito, ético-estético-ascético. Apoiando-se na concepção de Askesis de Foucault (como uma questão de exercício e de cuidado), Schmid atém-se a um modelo prático-moral da filosofia intermediária de Nietzsche, qual seja, da 'naturalização' do ascetismo, enquanto exercício da liberdade e domínio sobre si. Esse modelo seria desenvolvido principalmente a partir do Zaratustra, numa estética-ética do criador, em que o perspectivismo e o experimentalismo de tal empreendimento se concretizaria em novas 'técnicas da existência'14.

Embora o próprio Nietzsche, em vários momentos, busque reduzir a ética à estética ${ }^{15}$, apontamos neste texto para a necessidade de analisar as diferenças entre a concepção estética da existência e as exigências éticas que se colocam no projeto de transvaloração dos valores. Se quisermos levar a sério Nietzsche como crítico da moral e como pensador ético é preciso questionar se a constituição do indivíduo além-da-moral, livre e autônomo ocorre unicamente na configuração estética da existência. É preciso, enfim, retomar criticamente os estudos de história natural da moral de Nietzsche e sua pretensão de superar a moralidade.

${ }^{14}$ Cf. SCHMID, 1992, p. 50-62.

${ }^{15} \mathrm{Cf}$. os fragmentos póstumos IX, 11(78) e IX, 11(79) - início - outono de 1881. 


\section{Referências bibliográficas}

DELEUZE, Gilles. Nietzsche e a filosofia. Rio de Janeiro: Ed. Rio, 1976.

FOUCAULT, Michel. Nietzsche, a Genealogia e a História. In Microfísica do Poder; trad. de Roberto Machado. Rio de Janeiro: Graal, 1992.

GERHARDT, Volker. Die Perspektive des Perspektivismus. In: Nietzsche-Studien 18. Berlim: de Gruyter, 1989, p. 260 - 281.

GIACÓIA Jr., Oswaldo. Labirintos da alma. Nietzsche e a auto-supressão da moral. Campinas: Editora da UNICAMP, 1997.

GIACÓIA Jr., Oswaldo. Nietzsche \& Para além de bem e mal. Rio de Janeiro: Jorge Zahar Ed., 2002.

HÖFE, Otfried (org.). Zur Genealogie der Moral. Berlim: Akademie Verlag, 2004.

HUME, David. A Treatise of Human Nature. New York: Dove Publications, 2003.

KANT, Immanuel. Crítica da razão prática. Lisboa: Ed. 70, 1989.

KANT, Immanuel. Fundamentação da metafísica dos costumes. In Col. Os pensadores. São Paulo: Abril Cultural, 1980.

MARTON, Scarlett. Extravagâncias. Ensaios sobre a filosofia de Nietzsche. São Paulo: Discurso Editorial/Editora da UNIJUÍ, 2000.

MARTON, Scarlett. Nietzsche: Das forças cósmicas aos valores humanos. São Paulo: Brasiliense, 1990.

NIETZSCHE, F. W. A gaia ciência. Trad. de Paulo C. de Souza. São Paulo: Companhia das Letras, 2001.

A genealogia da moral. Trad. de Paulo C. de Souza. São Paulo: Companhia das Letras, 1998.

. Além do Bem e do Mal. Prelúdio a uma Filosofia do Futuro; trad. de Paulo

C. de Souza. São Paulo: Companhia das Letras, 1992.

Assim falou Zaratustra. São Paulo: Círculo do Livro, 1990.

Aurora. Trad. de Paulo C. de Souza. São Paulo: Companhia das Letras, 2004.

. Crepúsculo dos ídolos, ou, Como se filosofa com o martelo. Trad. de Paulo

C. de Souza. São Paulo: Companhia das Letras, 2006.

Ecce homo. Como alguém se torna o que é. Trad. de Paulo C. de Souza. São Paulo: Companhia das Letras, 1995.

. Humano, demasiado humano. Trad. de Paulo C. de Souza. São Paulo: Companhia das Letras, 2000.

O Anticristo. Maldição ao Cristianismo; Ditirambos de Dioniso. trad. de

Paulo C. de Souza. São Paulo: Companhia das Letras, 2007. 
Sämtliche Werke. Kritische Studienausgabe (KSA). 15 vols. Organizada por Giorgio Colli e Mazzino Montinari. Berlim: de Gruyter, 1988.

Werke. Kritische Gesamtausgabe (KGW). 36 vols. Organizada por Giorgio Colli e Mazzino Montinari. Berlim: de Gruyter, 1967-2001.

PASCHOAL, Antonio E. \& FREZZATTI JR., Wilson A. (orgs.) 120 anos de "Para a genealogia da moral”. Col. Nietzsche em perspectiva. Ijuí: Ed. UNIJUí, 2008.

RÉE, Paul. Gesammelte Werke (1875-1885). Org. por Hubert Treiber. Berlim: de Gruyter, 2004.

SCHOPENHAUER, Arthur. Werke in fünf Bänden. Zurique: Haffmans Verlag, 1999. SCHOPENHAUER, Arthur. Sobre o fundamento da moral. São Paulo: Martins Fontes, 2001.

SCHMID, Wilhelm. Uns selbst gestalten. Zur Philosophie der Lebenskunst bei Nietzsche. In: Nietzsche-Studien 21. Berlim: de Gruyter, 1992, p. 50 - 62.

SCHRÖDER, Winfried. Moralischer Nihilismus. Radikale Moralkritik von den Sophisten bis Nietzsche. Stuttgart: Reclam, 2005.

ZITTEL, Claus. Ästhetisch fundierte Ethiken und Nietzsches Philosophie. In: Nietzsche-Studien 32. Berlim: de Gruyter, 2003, p. 103 - 123.

E-mail: clademir.araldi@gmail.com

Recebido: 10/2008

Aprovado: 11/08 